\begin{tabular}{lll}
\hline & & \\
Review Article & $\begin{array}{l}\text { Yönetim, Ekonomi, Edebiyat, } \\
\text { İslami ve Politik Bilimler } \\
\text { Dergisi,3(1): 110-140, }\end{array}$ & $\begin{array}{l}\text { JOMELIPS - Journal of } \\
\text { Management Economics Literature } \\
\text { Araştırma Makalesi }\end{array}$ \\
Islamic and Political Sciences \\
DOI: 10.24013/jomelips.430711 & 30 Haziran/June, 2018 & e-ISSN :2547-9512 \\
\hline
\end{tabular}

\title{
Richard Sennett'ın Eserlerinde Kapitalist Kültürün Dönüşümü
}

\section{Merve KÜÇÜKİSLAMOĞLU ${ }^{* *}$}

${ }^{1}$ Yıldız Teknik Üniversitesi, Sosyal Bilimler Enstitüsü, Siyaset Bilimi ve Uluslararası İlişkiler ABD Yüksek Lisans Öğrencisi

Prof. Dr. Ester RUBEN ${ }^{2}$

${ }^{2}$ Yıldız Teknik Üniversitesi,Siyaset Bilimi ve Uluslararası İlişkiler Bölümü

$\ddot{O} z$

$\mathrm{Bu}$ çalışmada esnek üretimle birlikte ortaya çıkan çalışma pratiklerine odaklanılmakta, yeni çalışma kültürünün ve buna bağlı olarak dönüşen birey yaklaşımının anlaşılması için çalışılmaktadır. Esnek üretimden önce var olan çalışma anlayışı ile karşıllaştırma yapılacak olan çalışmada, dönüşümün net bir şekilde ortaya çıkarılması amaçlanmaktadır. Richard Sennett'ın bu dönüşümü nasıl değerlendirdiğine, yeni üretim biçimi ile birlikte çalışma ile ilgili anlamlarda ortaya çıkan değişime odaklanılacaktır. Üretim düzeni ile ilgili süreçlerin esnetilmesine dayanan yeni üretim anlayışı ile kısa zamana odaklanmış hedeflerin belirlenmesinin, kısa süreli sözleşmelerle ya da geçici çalışma anlayışının yaygınlaşmasının insanların çalıştıkları kurumlarla, yapmakta oldukları işlerle ve birlikte çalışıtıları insanlarla kurdukları bağların zayıflamasına yol açtı̆̆ görülecektir. Bu durumun 'makbul' bir birey anlayışı tanımlamasını beraberinde getirdiği; geçmişini kolaylıkla geride bırakabilen, yeni süreçlere uyum sağlamaya açık, kısa sürede yeni çözümler üretebilen, yeni ortam ya da işlere kolaylıkla uyum sağlayabilen insanların yeni üretim anlayıșı ile tercih edilir oldukları görülmektedir. Tüm bu kriterlerin ilk bakışta sorunlu olmadığı düşünülmekle birlikte insanların geçmişleri ile kurdukları bağın değersizleştirildiği, esnek üretimden önce değerli görülen deneyimlerin bu süreçle birlikte anlamsızlaştığı; tüm bunlara bağlı olarak sadakat, özveri, bağlllık gibi duyguların da olumsuz olarak algılanmaya başlandığı görülmektedir. Bunlara bağlı olarak geleceğin belirsizliği karşısında yaşanılan güvensizliğin insanlar üzerinde ciddi tahribata yol açtığı savunulmaktadır.

*Sorumlu Yazar (Corresponding Author):

Yıldız Teknik Üniversitesi, Sosyal Bilimler Enstitüsü, Siyaset Bilimi ve Uluslararası İlişkiler ABD Yüksek Lisans Öğrencisi
Geliș (Received) : 05.06.2018

Kabul (Accepted) : 26.06.2018

Basım (Published) : 30.06.2018 
Anahtar Kelimeler: Esnek Üretim, Sennett, Esnekleşme, Ücretli Çalışma, Taşeron The Transformation of Capitalist Cultures in Richard Sennett's Works

\begin{abstract}
This study focuses on the work practices that emerged with the flexible production, and the new study is attempting to understand the cultures and the resulting individual approach. It is aimed to reveal the transformation in a clear way in the study which will be compared with the existing working understanding before flexible production. It will be focused on how Richard Sennett evaluates this transformation and on the change, that has emerged in the meaning of working with the new mode of production. It will be seen that the determination of short-time focused goals, the adoption of short-term contracts or temporary working understanding led to the weakening of the bonds that people build with the institutions and people they work with. This situation brings definition of a 'reasonable' individual understanding with itself, it is seen that people who are able to leave behind the past easily, adapt to new processes, produce new solutions in a short period of time and adapt easily to new environments or works are preferred with new production understanding. While all these criteria are thought to be unproblematic at first glance, the experience that prevails before flexible production, where people are tied to their past, becomes meaningless in this process; it is seen that feelings such as loyalty, self-sacrifice, commitment start to be perceived as negative according to all these. It is argued that the insecurity in the face of uncertainty of the future leads to serious destruction of people.
\end{abstract}

Keywords: post-fordism, Richard Sennett, flexible production

\title{
Giriş
}

Kapitalist üretim tarzının ve makineleşmiş üretimin yaygınlaşması sürecinde sanayi kapitalizminden önce toprak sahibine bağımlı olan insanlar ve loncalara bağlı zanaatkârların giderek fabrika sahiplerine bağımlı hale geldikleri bilinmektedir. Sanayi öncesinde hâkim yaşam tarzının kapitalist ekonomiden çok farklı olduğu tüketim nesneleri ile ilgili ihtiyaç anlayışında ciddi değişimler yaşanmış olduğu bilinmektedir. Hobsbawm (2003, s. 81), bu farkı "geçmişin ahlaki iktisadı ile zamanın kapitalistinin iktisat mantığı arasındaki çelişki" olarak nitelendirmiştir. Kapitalist üretim anlayışı farklı dönemlerde farklı şekillerde 
örgütlenmek ile birlikte temel mantığı hep aynıydı; işçileri aşırı çalışmaya zorlama, üretilen her değerin metaya dönüştürülmesi ve satılması, artı-değerin sağlanması, daha çok mal ve art1-değer üretebilmek uğruna sermayenin genişletilmesi için çaba gösterilmesi olarak ortaya çıkmaktadır (Beaud, 2003, s. 288).

Sanayi kapitalizminin içine düştüğü kriz ve etkilerinden kurtulabilmek için uygulanmaya başlanan işin parçalarına ayrılması, hareketli bant üzerinden ve üretimin sistematik bir șekilde sürdürülmesine dayanan Fordist sistem, verimliliğin artırılması ve daha kısa sürede daha çok ürünün ortaya çıkarılmasına olanak sağlıyordu (Beaud, 2003, s. 202). Daha kısa zamanda daha fazla ürün elde edilebilmesi ekonomik sistemin düştüğü krizden kurtulmas1 için yeterli değildi elbette; bu ürünlere sahip olabilmek için daha çok çalışacak, daha çok tüketecek yeni bir birey anlayışının ortaya çıkması kaçınılmaz olacaktı. Dolayısıyla fordist üretim modelinin sadece bir üretim biçimi olarak ortaya çıktığını söylemek eksik olacaktır; bir yaşam tarzı olarak ortaya çıkmakta, insanların ihtiyaç, zaman ve arzularını şekillendirmektedir (Harvey, 2010, s. 158).

Kapitalist üretim anlayışının kâr ve güce odaklanması bunun sonucunda aşırı üretim kapasitesine ulaşması ile belli dönemlerde iktisadi krize yol açtığı görülmektedir (Dowd, 2013, s. 219). İşin en ufak parçalarına ayrıldığı, her işçinin belli bir parçayı gerçekleştirdiği fordist üretim modelinin de aynı şekilde sürdürülemeyeceği anlaşıldığında yeni üretim ve çalışma anlayışlarının ortaya çıkması kaçınılmaz olmuştu. Esnek üretim biçiminin fordist üretimden en belirgin farklarını sistemin katılıklarının ortadan kaldırılması, emek süreçleri, işgücü piyasaları, üretim ve tüketimle ilgili kabul gören anlayışların katı kurallara bağlı olmasının önüne geçilmesi ve emek süreçlerinin ve işleyişlerinin esnetilmesi olarak siralanabilir (Harvey, 2010, s. 170).

$\mathrm{Bu}$ çalışmada yeni üretim biçimi ile birlikte ortaya çıkan yeni birey anlayışı ve dönüşen çalışma pratiklerinin insanlar üzerinde ne gibi etkiler bıraktığının karşılaştırmalı bir şekilde analiz edilmesine çalışılacaktır. Öncelikli olarak Richard Sennett tarafından bu dönüşümün nasıl görüldüğünün ortaya çıkarılması için çalışılacak ve yaşanan olaylar üzerinden Türkiye'de bu değişimin nasıl deneyimlendiğine değinilecektir. Sennett'ın eserleri incelenerek söz konusu dönüşümün etkileri ortaya çıkarılacak ve konu ile ilgili literatür taraması yöntemine başvurulacaktır. Dönüşümün çalışanlar açısından nasıl deneyimlenmekte olduğunu eserlerinde ayrıntılı bir şekilde ortaya koymuş olan Sennett 
(1997, s. 31), yeni üretim anlayışının hükümet ve şirket bürokrasilerinin esnetilmesine dayandığını, bu esnekliğin kurumların çalışanlara güvence sağlayacak örgütlenmeye sahip olmalarına engel olduğunu, mesleklerin piyasa ihtiyaçlarına göre değişikliklere açık hale getirildiklerini, kısa vadeli iş anlayışının uzun yıllar aynı işlere emek verme anlayışının yerine geçtiğini ifade etmiştir. Bu dönüşümün çalışanlar tarafından nasıl tecrübe edildiği bugünkü üretim anlayışı ile çalışma pratiklerinin nasıl dönüşmüş olduğu ve insanların buna karşı geliştirdikleri tepkilerin neler olduğu Sennett'ın eserleri üzerinden anlaşılmaya ve esnek üretimle birlikte egemen hale gelen kültürün esnek üretimden önceki kültürden hangi açılardan farklı olduğunun ortaya çıkarılacaktır.

Kapitalizmin kültürü ifadesinde yer alan kültür kelimesi antropolojik bir anlama işaret etmektedir, bir topluluğu meydana getiren bireylerin çevreleriyle, farklı topluluklarla kurdukları ilişkiyi etkileyen süreçler ve bireylerin davranışlarını belirleyen zihinsel ve fiziksel etkinlikler kastedilmektedir. Dolayısıyla kapitalizmin kültürü, kapitalizmin geçirmiş olduğu süreçlerle birlikte edindiği anlayışları, ahlaki ve duygusal yapısını ifade etmektedir. Bununla birlikte bu șekilde ifade edilmesinin bir diğer sebebi ise yıllar boyunca devam eden değişen, dönüşen, yenilenen ve gelişen bir süreç olduğunun vurgulanmasına imkân tanımak olmasindandır (Macfarlane, 1993, s.17). Sennett, (2011, s.10) kültür kelimesinin antropolojik bir anlam ifade ettiğini, kapitalizmin ortaya çıkmasına sebep olduğu değerler ve pratikleri kastettiğini belirtmiştir. Kısaca ifade etmek gerekirse, kültür ile kastedilen üretim biçiminde ortaya çıkan değişikliklerin toplumsal hayata nasıl yansıdığı, buna bağlı olarak gündelik davranışların, alışkanlıkların, anlamların ve yaşayış biçimlerinin nasıl bir seyir izlediği ve zaman içinde nasıl dönüştüğüdür.

\section{Esnek Üretimle Birlikte Çalışmanın Dönüşen Anlamı}

Üretim şekillerinde ortaya çıkan dönüşümler, tüm toplumsal yapı ve değerlerle ilgili anlamların da dönüşümüne yol açmaktadır. Kapitalist üretim biçimi ile birlikte piyasanın ekonomik ve toplumsal alanda kilit rol oynamaya başlaması ve yaşanan krizlerin çözüme ulaştırılması için benimsenen esnek üretim anlayışı ile yeni bir birey anlayışının ortaya çıkmış olduğu görülmektedir. Dönemin koşullarına göre belirli davranışların ortaya çıktığı bilinmektedir. Erich Fromm (1996, s. 13-14), 18. ve 19. yüzy1lda insanların kâr elde etmeye ve bunun için sömürüye başvurduklarını, 20. yüzyıla gelindiğinde tüketime yönlendirilmiş 
olan bireyin pasif bir karaktere sahip olduğuna değinmiştir. 21. yüzyıla gelindiğinde ise tüm süreçlerin belirsiz bir hal aldığı, baskı ve kontrol mekanizmalarının insanları daha da pasifleştirmiş olduğu ve güvencesiz, geçici, belirli sürelerle çalışma anlayışının benimsenmiş olduğu bilinmektedir. Gorz (2014, s. 81-82), özellikle esnek üretim anlayışı ile çalışma toplumunun yerinden edildiğini; yeteneklerinin çok azını kullanan bireylerin ancak kısa süreli istihdam edildikleri işlerde çalıştıkları, dolayısıyla esasen herkesin işsiz olduğunun söylenebileceği bir topluma dönüşmüş olduğunu ifade etmiştir. Ona göre, ortak bir bilincin yaratılmasına engel olan esnek üretim sürecinin mesleklerin değersizleşmesine, insanların vasıfsızlaştırılmasına ve insanların yaptıkları işleri benimseyememelerine yol açmaktadır.

Çalışmanın insanlar için anlamının değişimine yol açan etkenlerden en önemlisinin zanaatkârlık anlayışının terk edilmesi olduğunu düşünen Sennett (2013, s. 32), bu anlayışın çok değerli olduğunu düşündüğünü her firsatta dile getirmekte ve bu anlayışa verdiği değerin sebeplerini Zanaatkâr isimli eserinde ayrıntılı bir şekilde tartışmaktadır. Zanaatkârı, emeğini araç haline getirmeyen, ortaya çıkarmakta olduğu ürünü en iyi şekilde yapabilmek için çaba harcayan ve dolayısıyla değil ürününe yabancılaşmak, onun yapımından keyif alan kişi olarak tanımlamıştır. Zanaatkârın emeği, ortaya çıkarılmakta olan ürünün nasıl yapıldığına, hangi adımların gerçekleştirilmesi ile ortaya çıktığına ve bundan daha önemlisi hangi işe yarayacağına dair anlamlı bir ilişki barındırması bakımından bugün insanların çalıșma ile kurdukları bağdan çok farklıdır. Bu ilişkiyi kurabiliyor olmaları aynı zamanda insanlara iyi bir şey yapıyor olduklarını hissetmelerine imkân tanımaktadır (Gaulejac, 2013, s. 133-134). Fabrikalarda üretimin yaygınlaşması ile zanaatkârlık anlayışının terk edilmiş olduğu bilinmekle birlikte, esnek üretim anlayışı ile zanaatkârlık anlayışından iyice uzaklaşılmış olduğu daha da hissedilir olmuş, insanların iyi bir şey yapıyor olduklarını hissetmeleri bir tarafa piyasa düzenine göre örgütlenmekte olan üretim anlayışı, çalışmanın insanlar için farklı şekillerde anlamlandırılmasına yol açmış ve esnek üretimle birlikte yaşanan bu dönüşüm daha ciddi şekillerde hissedilir hale gelmiştir.

Sennett'e (2013, s. 53-54) göre, zanaatkârlığın ortadan kalkmış olmasının en ciddi sonucu, bugün piyasa koşullarına ayak uydurmak için çaba gösteren insanların zanaatkârların ortaya çıkarmakta oldukları ürünle ilgili almış oldukları zevkten mahrum olmalarıdır. Esasen burada zevk ile kastedilen sadece yapılan işten keyif alma anlamına gelmemekte insanların yaptıkları işleri anlamlı bulmaları, işe yarar bir şey yaptıklarını hissetmeleridir. 
Sennett (2013, s. 65) zanaatkârlığın terk edilmesi ile çalışma anlayışında işin nasıl yapıldığı ile ne işe yarayacağı arasında bir çelişki yaratılmış olduğunu; doğruluk ve işlevsellik anlayışlarının birbirlerine karşıt iki anlayış olarak ortaya çıkmasına yol açtığını ifade etmiştir. Eserinin kusursuz olmasını amaçlayan zanaatkârdan, daha fazla üretip, daha çok kazanmayı amaçlayan bu nedenle de kusursuzluğa değil kısa zamanda kullanılabilecek ve piyasada tercih edilecek bir ürünün ortaya çıkarılmasına odaklanmış çalışma anlayışına geçilmiş olduğu görülmektedir. Öncelikle şunun tekrar edilmesinde fayda var ki, bu çalışma anlayışı yani zanaatkârlığın terk edilerek kâra odaklanan anlayışın kabul görür hale gelmesi esnek üretimle birlikte ortaya çıkmış değildir; fakat esnekleşme ile birlikte çalışma ile ilgili anlamların daha da muğlaklaşmış olduğu, anlayış olarak da zanaatkârlıktan çok uzaklaşılmış olduğu bilinmektedir. Zanaatkârlıkta iş birliği ve birlikte üretim yapma anlayışı hâkim iken esnek üretim anlayışı ile birlikte rekabetin ön plana çıkarılmış olduğu, yeteneğin bir işi iyi yapabilme olarak değil, rekabet ortamına uyum sağlayabilme ile özdeşleştirilir olduğu görülmektedir.

Sözü edilen bu durumu yirmi beş yıl ara ile gözlemlediği Boston'daki bir firında sürdürülen üretim üzerinden anlamlı hale getiren Sennett, yirmi beş yıl sonra döndügüü fırındaki gözlemlerinin kendisini çok şaşırttığına yer vermiştir. Onu şaşırtan konulardan ilki, fiziki şartların iyileştirilmiş olması ile birlikte burada çalışan işçilerin işleri ile ilgili tatmin yaşayamıyor olmalarıydı. Bu durumun birçok nedeni olduğu gibi, Sennett (2008, s. 70-71) için önemli olan nedenlerden biri önceden işçilerin elleriyle yaptıkları birçok işlemin makinelerle çok hızlı bir şekilde gerçekleştiriliyor olmasının işçilerin ekmek yapımı ile ilgili herhangi bir bilgi sahibi olmalarına engel oluyor olması, bu nedenle işleri ile kurmakta oldukları bağın çok zayıf olması, bilgisayar ekranından komut vererek pişirdikleri ekmekler yerine herhangi başka bir şey üretiyor olsalar dahi onlar için bir anlam ifade etmeyecek olmasidir.

Üretim biçimlerinde ortaya çıkan dönüşümler yetenek ve başarı ile ilgili kriterlerin de dönüşümüne yol açmıştır. Burada akla gelebilecek olan soru ise bu kriterlerin nasıl ve kimler tarafindan belirlendiğidir. Üretim ve çalışma ile ilgili düzenlemelerin sadece ekonomi alanını ilgilendiren meseleleri etkilemekle kalmayıp, insanların tüm yaşantılarını şekillendirmede büyük rol oynadığg bilinmektedir. Sözgelimi Guy Standing (2017, s. 73), zanaatkârlığın gözden düşmesi ile zanaatkârlar arasında düzen ve ortaklık sağlayan kurumların da ortadan kaldırılmış olduğunu, meslek grupları açısından belirli birçok 
durumun belirsiz hale getirildiğini özellikle esnek üretimin egemen hale gelmesi ile sürecin iyice belirsizleştiğini, böylece meslek gruplarının ve çalışanlarının kontrol altına alındığını, sürecin piyasanın ihtiyaçları doğrultusunda yönlendirilmekte olduğunu ifade etmiştir.

Dieter Duhm (2015, s. 78), bu durumun egemenlik ilişkileri bağlamında anlamlandırılabileceğini tartışmış ve sermayenin emek üzerindeki egemenliğinin sadece üretim alanında değil, hayatın her alanında belirleyici olduğunu; daha çocukluk yıllarından başlanarak emek gücünün kontrol altına alındığını, okul, yurt, üniversite, devlet daireleri gibi kurumları aracılığıyla otoritenin emek gücünün oluşturulmasına ve çalışma düzeninin istenildiği şekilde sürdürülmesine hizmet edecek şekilde düzenlendiği ifade etmiştir.

Sennett (2005, s. 84) de benzer şekilde yetenekle ilgili kriterlerin nasıl belirlendiğinin önemli olduğunu belirtmiş, yetenek yarışmalarını örnek göstererek bu durumu açıklamış; yetenekle ilgili kriterlerin yarışmalar, yarışmayı düzenleyen ve yarışmalara hazırlayan kurumlar tarafından şekillendiğini belirtmiştir. Dolayısıyla başarı ve başarısızlığın belli kriterler ve belli gruplar etrafında şekillenmekte olduğunun açık olduğunu ve bazı insanların yetenekli olarak nitelendirilirken diğerlerinin yeteneksiz olarak nitelendirildiklerini ifade etmiştir. $\mathrm{Bu}$ durumun sadece yetenekle ilgili yarışmalar için geçerli olmadığını, yetenekle ilgili düzenlenen her sınavın, işe alımlarda belirlenen her kriterin belirli normlar ve kurallar çerçevesinde düzenlendiğini söylemenin mümkün olduğunu eklemiştir. Burada vurgulanmak istenen modern toplumlarda başarısızlığın bir gösteren ile somutlaştırılmak istendiği ve bunun sonucunda insanların başarısız olarak nitelendirilen bir durumla karşı karşıya kaldıklarında bunun kendi sorumluluklarında olduğunu ve bu nedenle de bireysel olarak başa çıkmaları gerektiğini kabullenmeleri gerektiği algısının yaratıldığıdır. $\mathrm{Bu}$ anlayışın yol açmakta olduğu sonuçlardan biri de zanaatkârlık anlayışının yani bir şeyi iyi yapmak için çabalamanın anlamsızlaşması, sadece belirli kriterlerin yerine getirilmesi için çalışılmasıdır; bununla beraber bir şeyi en iyi şekilde yapma anlayışının yerini bireyselliğin ve rekabetin almış olduğu görülmektedir.

Tüm bu yaşanan dönüşümden yola çıkarak Sennett (2013, s. 376), zanaatkârın merak duygusu ile yola çıkan, ortaya çıkarılmak istenen nesnelere ve onun en iyi şekilde yapılabilmesi için gerçekleştirilmesi gereken süreç ve adımlara odaklanan, sadece ortaya çıkacak sonucu değil, yapım sürecinde karşılaşılan sorunları önemseyerek onları da en iyi şekilde yönetmeyi amaçlayan kişi olarak tarif etmiştir. Sennett'ın zanaatkârı ve onun sahip 
olması beklenen nitelikleri bu denli önemsemenin öncelikli sebebi, bu anlayışın insanın kendi ortaya çıkarmakta olduğu üründen uzaklaşmasına engel olması, o ürünün ne işe yarayacağına dair fikir sahibi olmasının ve iyi bir şey yaptığını hissetmesinin, buna bağlı olarak da yaptığı işten gurur duymasına imkân yaratmasıdır. Bunun yanı sıra Sennett, çalışma esnasında sürdürülen pratiklerin ve alışkanlıkların insanların tüm hayatlarına sirayet edeceğini düşünmektedir ve zanaatkârlıkta benimsenen uzun vade anlayışının, tekrara ve tecrübeye dayanan çalışma kültürünün sürdürülmesinin insanların gündelik hayatları için de değerli olabileceğini sıklıkla ifade etmiştir. Sennett, mücadele etme, herhangi bir sorunla karşılaşıldığında mücadelen kaçmak yerine daha fazla çaba göstermeyi tercih etme, dolayısıyla bağlılık, sadakat, özveri gibi esnek üretimle birlikte egemen hale gelen kısa vade anlayışının değersizleştirdiği anlayışların sürdürülmesinin mümkün olabileceğini düşünmektedir. Özellikle esnek üretimin yaygın hale gelmesi ile zanaatkârlık anlayışından iyice uzaklaşıldığı, tüm süreçlerin yerini kısa vadeli zaman anlayışına bırakmış olduğu, mevcut süreçlerin belirsizleştiği, belirsizliklerin gelecekle ilgili plan yapmaya fırsat vermediği görülmektedir. Bu dönüşümün Sennett açısından dikkate değer olmasının sebebi, süreçlerin toplumsal hayatı ve kültürü de etkilemekte olması, insanların çalışma düzenine ayak uydurabilmek için içselleştirmek zorunda kaldıkları alışkanlıkların tüm hayatlarında egemen hale gelmiş olmasındandır.

Kapitalist üretim anlayışı kelimelere ve anlayışlara getirmiş olduğu nitelendirmelerle emekleri ile çalışmak zorunda kalan tüm insanları belli şekillerde davranmaya ve düşünmeye mecbur bırakır ve "kapitalizmde çalışma insanın hayatında zıt görünümlerle bulunmaktadır: Verimlilik aslında kısırlık, etkinlik aslında durağanlık, üretkenlik aslında tükenmişlik getirir." (Senemoğlu, 2017a: s. 107) İşin sadece bir parçasını yaparak tüm hayatını geçiren işçi zanaatkârın ürettiği ürünlerden çok daha fazlasının üretmiş olmakla birlikte, ortaya çıkan ürünün kendisine ait olduğunu hissedemeyecektir; fakat verimliliğin ve daha fazla ürün ortaya çıkarmanın değerli olarak görüldüğü sistemde bu durumun yol açtığı tahribata karşı mücadele etmenin kolay olmadığı görülmektedir.

\section{Kurumların Dönüşen Yapısı ve Yol Açtığı Belirsizlikler}

Kısa vade anlayışının gelecekle ilgili plan yapılamamasına yol açarken ortaya çıkan belirsizliklerin insanların işleriyle ilgili özveride bulunmalarını anlamsızlaştırdığı 
bilinmektedir. Esnek üretimin belirgin bir şekilde etkisini göstermesi ile kabul gören davranış biçimlerinin geçmişini terk edebilme, çalışılan kurum, şirket ve çalışma arkadaşları ile sadakat, bağlılık ilişkisi kurulmadan çalışılabilmesi, sürekli yer ya da görev değişiklikler ile baş edebilme, bir sorunla karşılaşıldığında onun çözümü için tek başına sorumluluk alma olarak ortaya çıkmakta olduğu görülmektedir. Sennett, bu duruma yol açan etkenlerden en önemlisinin kurumların işleyiş biçimlerinin dönüşmesi olduğuna inanmaktadır. Öncelikle belirtilmesinde fayda var ki, neoliberal devlet anlayışının emek gücünün ve piyasa koşullarının sermayenin çıkarını koruyacak şekilde düzenlenmesini gerekli hale getirdiği, bununla birlikte sermayedarların ulus aşırı hareket edebilmelerinin önünün açıldığı; toplumsal dayanışma, işçi örgütlenmeleri gibi oluşumların ancak piyasanın işleyişine zarar vermeyecek şekilde faaliyet göstermelerine izin verildiği görülmektedir (Harvey, 2015, s. 83). Buradan da anlaşılacağı gibi, yapısal bir dönüşüme yol açacak olan bu yaklaşım öncelikle kurumların örgütlenme biçimini dönüştürecek ve yeni bir çalışma anlayışının yerleşmesine yol açacaktır. Bu dönüşüm elbette birdenbire ortaya çıkmış ve insanların hayatlarında hiç beklemedikleri bir şekilde değiştirmiş değildir; çalışma hayatına uyum sağlamak için çaba göstermek zorunda kalan insanların çoğu zaman yaşamakta oldukları tahribatın neden kaynaklandığını anlamaları da kolay değildir. Burada vurgulanmak istenen kurumların esnetilmiş koşullarının insanlara güvenceli bir çalışma anlayışı ortaya çıkarmaktan uzak olmasıdır.

Kurumlarda ortaya çıkan dönüșümün en dikkate değer olan tarafı esnek üretimle birlikte hiyerarşik ve merkezi yapılanmanın ortadan kalkmış olmasıdır; çünkü piyasanın çok hızlı değişmesi ile birlikte ortaya çıkan anlayış piyasanın ihtiyaçlarına çok kısa sürede cevap verilmesidir. Merkezi örgütlenmede bu çok hızlı bir şekilde gerçekleşememektedir; çünkü karar alma mekanizmaları çok katmanlı olduğundan sürecin uzaması söz konusu olmaktadır (Gorz, 2014, s. 23). Sennett (2011, s. 36), kurumların dönüşümü ile ilgili hiyerarşik yapılanmaların yani piramit şeklindeki örgütlenmenin ortadan kalkmış olmasının ciddi değişikler ortaya çıkarmış olduğunu, eski tarz örgütlenmelerin işin yapılışı ile ilgili belli adımların izlenmesine dayandığını, esnek üretimle birlikte bu sürecin belirsizleştiğini, işin tamamlanmasına öncelik verildiğini ve belli adımların ortadan kaldırıldığını ya da işlemler arasında belli sıraların takip edilmesi gerekliliğinin geçersizleștiğini ifade etmiştir. Sennett (2011, s. 36), bu şekilde kurumsal örgütlenmenin ortaya çıkarmış olduğu sonuçlardan birinin taşeronlaşma anlayışının yani işin belirli kısımlarının başka firmalar tarafından 
üstlenilmesinin yaygınlaşması olduğunu belirtmiştir. Çalışanlarla ilgili sorumluluk almaktan mümkün olduğunca kaçınmak isteyen işverenin taşeronlaşma anlayışının yaygınlaşması ile bunu kolaylıkla gerçekleştirebildiğini; sözgelimi iş kazası riski fazla olan işlerin taşeron firmaya devredilmesini mümkün kılan bu anlayışın güvencesiz ve kısa süreli çalışma anlayışının yaygınlaşmasına yol açmakla birlikte, işlerin belirsizleşmesi ve buna bağlı olarak da sürekli değişen piyasa ihtiyaçlarına göre işlerin tamamlanmasına odaklanan işverenlerin çalışanları fazla çalışmaya zorladıkları bilinmektedir.

Esnekleşme ile birlikte yaygın bir şekilde uygulanan taşeronlaşma anlayışının çalışanlar açısından çok büyük eşitsizliklerin yaşanmasına yol açtığını belirten Thebaud-Mony (2012, s. 221), fabrikaların yurttaşlarının haklarının korunması için sıkı bir denetim uygulamayan ülkelere taşınmasının çalışanların yaşadıklarının önemsenmeden bir üretim planı uygulanmasına yol açtığını, yaşadıkları ülke, milliyet ve zenginliklerine göre hakları belirlenen insanların zor şartlara mahkum edildiklerini ve bunun sömürgeci anlayıştan farklı olmadığını dile getirmiştir.

Kurumların yapısal olarak dönüşümü ile ilgili dikkate değer sonuçlardan biri de zaman anlayıșında ortaya çıkan değişimdir; Sennett'ın (2011, s. 37)deyimi ile uzun vade anlayıșının yerini kısa vade anlayışına bırakması, kurumlarda ortaya çıkan süreçlerin belirsizleşmesine yol açmakta, yakın ya da uzak gelecekte insanların işleri ile ilgili ne gibi değişiklikler yaşayacaklarına dair öngörü sahibi olmalarına engel olmaktadır. Esnek üretim anlayışından önce var olan durumun belirli görevlerin tanımı ve bu görevlerin yerine getirilip getirilmediğinde yaşanacakların önceden belirlenmesine dayandığını ifade eden Sennett, esnek üretimle birlikte bu süreçlerin tamamen belirsizleştiğini ifade etmiştir. Kurumların esnetilmiş yapısının bu duruma yol açtığını söylemek yanlış değildir; çünkü belirli işleyiş şekillerinin ortadan kaldırılması ile günün üretim ihtiyaçlarının karşılanabileceği şekilde çalışma düzeninin ve çalışma gruplarının yeniden kurulduğu bilinmektedir. Dolayısıyla çalışanların her yeni görev ve çalışma ortamında ayakta kalabilmesini gerekli hale getiren bu sistem, insanların belirsizlikler karşısında göstermiş oldukları davranışların başarı kriteri olarak ortaya çıkmasına yol açmaktadır.

Bunların yanı sıra yeni örgütlenme biçimlerinin yeni kontrol mekanizmaları ortaya çıkarmış olduğuna vurgu yapan Sennett (2011, s. 38), Foucault'un panoptik gözetleme kavramının esnek üretimle birlikte ortaya çıkan kontrol mekanizmalarını açıklamak için anlamlı 
olduğunu düşünmekte ve fordizmde de benzer şekilde üretim sürecinin kontrol altında tutulması ile birlikte esnek üretimle daha karmaşık hale gelen iş örgütlenmesinin hayatın her alanında kontrolün sağlanarak sürdürüldüğünü ifade etmektedir. Esnek üretimle birlikte söz konusu olan rekabetin de yeni kontrol biçimlerinde rol oynadığını söylemek mümkündür; performans odaklı çalışma anlayışı aynı iş yerinde çalışmakta olan insanların birbirlerini rakip olarak görmelerine yol açmaktadır ve bu durumun çalışanların kendi aralarında bir kontrol mekanizması geliştirmeleri ile sonuçlanmaktadır. Kısaca ifade etmek gerekirse, esnek üretimin sürdürülmesinin disiplin sağlanması üzerine kurulu olmadığı, gözetimin ön plan çıkarıldı̆̆ı görülmektedir (Gaulejac, 2013, s. 94).

Sennett (2008, s. 83), Karakter Aşınması isimli eserinde uzun yıllardır kendi barını işleten, bir reklam şirketinden aldığı iş teklifini değerlendirmek, tecrübelerini kullanarak yeni bir şeyler yapmak isteyen bir kadının yaşamış olduğu deneyim bu duruma örnek olarak gösterilebilir. Rose ismini verdiği kadının yeni çalışma ortamında yaşamış olduğu tek sorun çalışanlar arasında yaşanan rekabet olmamakla birlikte, iş arkadaşlarının yeni yetenek anlayışına uygun olarak onun tecrübelerini değersiz görmelerinin onu ciddi anlamda etkilemiş olduğu görülmüştür. Bunu ona hissettirmeleri, her an değişime hazır olma anlayışını çok kısa bir zamanda içselleştirememesi nedeniyle onu dışlamaları kendisini işe yaramaz, günün koşullarına ayak uyduramaz olduğunu hissetmesine yol açmıştır. Dolayısıyla esnek üretimden önce yönetici grubunda bulunan kişilerin değerlendirmelerini dikkate almak zorunda olan insanların bugün aynı ortamda çalıştıkları kişilerin de değerlendirmelerine maruz kaldıkları ve çok daha rahatlıkla gözlemleyebilen çalışma arkadaşlarının birbirlerini çok daha ciddi bir baskıya maruz bırakmakta oldukları görülmektedir.

\section{İş Birliği ve Rekabet Anlayışının Esnek Üretimle Birlikte Dönüşümü}

Esnek üretimle birlikte kurumların yapısal olarak göstermiş oldukları değişimler sadece işin yapılış şeklini, çalışma alışkanlıklarını değiştirmekle kalmamış; rekabet ve iş birliği ile ilgili anlayışı da değiştirmiştir. Fordist üretimden esnek üretime geçişle birlikte görevlerin daha parçalı bir hale gelmiş olması ve yapılması gerekenlerle ilgili talimatların anında ilgili çalışana gönderilmesi merkezi kontrolün ciddi bir şekilde sağlanmasına yol açarken diğer taraftan yapılması gerekenlerle ilgili çalışanların tek başına sorumluluk almaları gerekli 
görülmeye başlanmıştır (Sennett, 2011, s. 43). Burada üzerinde durulmak istenen konu, esnek üretimin çalışanları katı kuralların sorumluluklarından kurtaracağına dair beklentinin yanıltıcı olduğu, hali hazırda çalışanların bu kurallardan kurtulmalarını sağlayan sistemin farklı şekillerde çalışanları zorladığı ve bu kez çalışanların farklı baskılara maruz kaldıklarıdır.

Rekabet ve iş birliği ile ilgili ortaya çıkan dönüşümlerden biri de takım çalışmasının ön plana çıkarılmış olması ve belli görevler için kısa süreli çalışma gruplarının organize edilmesidir. Bu takım çalışmasını organize eden takım yöneticisinin grup çalışanları ile eșit statüdeymiş gibi davrandığı, gruba çalışanlar arasında iletişimi sağlayan ve yapılması gerekenleri ileten kişi olarak dâhil olduğu görülmektedir. Bu durum, işin nasıl yapılacağını belirlenmesinin ve ortaya çıkan sonuçların takım çalışanları tarafından üstlenilmesine yol açmakta ve takım yöneticisinin sorumluluk almaktan kaçmasına firsat yaratmaktadır (Sennett, 2008, s. 115). Esnek üretimle birlikte bürokratik yapılardaki ara katmanların ortadan kaldırılması ile mümkün olan bu çalışma düzeninde, başarısızlıklarla ilgili sorumluluk almayan takım liderlerinin varlığının yeni bir otorite biçimi olarak işlev gördüğünü ifade eden Sennett (2008, s. 117), çalışanın değil işverenin lehine olacak şekilde bir düzenin ortaya çıkmış olduğunu belirtmiştir. Bu durum aynı zamanda rekabet anlayışını da şekillendirmektedir, takımda çalışanlar arasındaki rekabetin gizlenmesine yol açmakta, kısa süreli hedeflere yönelik bir arada olan çalışanlarının istek ve sorunlarının görmezden gelinmesini kolaylaştırmaktadır; takım olmanın vurgulanması ile çalışanların şikayetlerinin olumsuz olarak algılanabileceğine dair yanıltıcı bir algı yaratılmakta ve bu nedenle çalışanların iş ile ilgili sorunlarını dile getirmekte zorlandıkları, başa çıkamayacakları bir sorunla karşılaştıklarında bunu çözmeye çalışmaktansa gitmeyi tercih ettikleri görülmektedir (Sennett, 2008, s. 121-122).

Bu durumun birçok sonucu olmakla birlikte Sennett'ın (2011, s. 45) üstünde durmaya değer gördüğü sonuçlarından biri, az sayıda kişiden oluşan karar alıcıların, yöneticilerin karar aşamasına çalışanları dâhil etmemesi, çalışanların tek yapmaları gerekenin verilen görevleri yerine getirmek olması, bu nedenle yaptıkları işi anlamlandırmada sorun yaşayan çalışanların aynı zamanda üretim sürecinde de yalnızlaştırılmış olmalarıdır. Zanaatkârlığın, işi birlikte yapmanın, yapılan üretime ve bu üretimin birlikte gerçekleştirildiği çalışanlara sadakat ve bağl1lık hissetmenin çok önemli olduğunu, anlamlı ve işe yarar bir şey yapılmakta 
olduğunun hissedilmesine olanak sağladığını düşünen Sennett, esnek üretimle birlikte egemen hale gelen kısa vade anlayışının buna hiç imkân bırakmadığını düşünmektedir.

Kısa vadeye odaklanmış anlayış ve yeni kurumsallaşma biçimi ile ortaya çıkan sorunlardan bir diğeri ise insanların birbirlerine karşı hissettikleri güven duygusunun azalmasına yol açmasıdır; rekabet ortamı, insanların uzun zaman bir arada çalışamamaları güvensizliğin daha ciddi bir şekilde hissedilmesine yol açmaktadır (Sennett, 2011, s. 47). Bu durumun insanların bir sorun yaşadıklarında bununla nasıl mücadele edecekleri konusunda kafa karışıklığı yaşamalarına yol açmakta olduğunu tahmin etmek zor değildir; kime güveneceklerini, kimden yardım isteyecekleri, kiminle birlikte mücadele edeceklerini bilemeyen insanlar mücadele etmektense, kabullenmeyi tercih etmek zorunda kalacaklardır. Bugün yaşanan süreçte, herkesi belli şekillerde etkilemesine rağmen olumlu değişimlerin mümkün olamamasının en büyük nedenlerinden birinin esnek üretimle birlikte ciddi bir şekilde hissedilen bireyselleşme ve yalnızlaşma anlayışı olduğunu söylemek mümkündür. Esnek üretimle birlikte toplumsal olarak kabul görmeye başlayan anlayışlardan birinin zamanın algılanışı ile ilgili olduğu; çalışma ile ilgili sürdürülen hiçbir süreçte uzun vadeye yer kalmadığ 1 görülmektedir. Esasen bu şu anlama gelmektedir; bir işi en şekilde yapmak için çaba harcamanın, yapılan işin anlamlı bir şekilde yapılabilmesi için sadakat ve bağlılık duyguları geliştirmenin kısa vadeye odaklanmış esnek üretim koşullarında varlığını sürdüremez olduğu görülmektedir.

Bu durumu 1970'li yıllarda Boston'da yapmış olduğu gözlemleriyle doğrulayan Sennett (2012, s. 191- 192), alkol problemi nedeniyle işyerinde sorun yaşayan kişinin diğer iş arkadaşları tarafından desteklendiğini, çalışma arkadaşlarının sorununu halledene kadar işlerinde ona yardım ettiklerini, kendisine güvendiklerini hissettirerek bu sorunla başa çıkmasında o kişiye yardım edebildiklerini görmüşsür. Esnek üretimle bu anlayışın ortadan kalktığı, insanların birbirlerine destek olacak kadar ilişki kurma zamanlarının olmadığı, olsa dahi bağ kurmanın tercih edilmediği bilinmektedir. Bugünün anlayışında önemli olan, değișen zaman ve koşullara hızlıca uyum sağlamaktır; bir çalışanın yaşamakta olduğu sorunların çözümü için çaba harcamaya vakit kalmamıştır.

\section{Esneklik Anlayışı ile Birlikte Yeni Bireyin Karakteri}


Sennett (2011, s. 58), insanların yașanan tüm olumsuzluklardan kendilerini sorumlu tutmak zorunda hissetmelerinin içine girdikleri mücadelede yalnız olduklarını ve suçluluk hissetmekle birlikte kendilerini işe yaramaz hissettiklerini ifade etmekte ve bu duyguyu da ‘ișe yaramazlık kâbusu’ olarak nitelendirmektedir.

Gaulejac (2013, s. 119-120), kurumların esnek üretimle birlikte benimsenmiş olan yeni yönetim biçiminin üç temel anlayışa dayandığını belirtmiş; bunları, çalışanların ekonomik bir savaşta olduklarına inandırılmaları, bireyselleşme anlayışının hayatın her alanına sirayet edecek şekilde benimsetilmesi ve çalışanların üretim süreçlerinin dişında tutularak sadece verilen görevleri yerine getirmeye odaklanmalarının sağlanması olarak sıralamıştır. Belirli bir hayat anlatısının şekillenmesine yol açan günün üretim ve tüketim ilişkileri, insanların bireyselleşme anlayışını daha çok benimseme, kendileri için çalışma ve daha fazlasını isteme, buna imkan sağlayan sistemin işleyişinin kendileri için avantaja çevirme eğiliminde oldukları görülmektedir. Kurumsal yapıların dönüşümünün sadece çalışma düzeninin değişmesine yol açmakla kalmadığı, insanların davranış ve düşüncelerine de sirayet ettiği bilinmektedir. Buradan yola çıkılarak Sennett'1n Karakter Așınması isimli eserinde esneklik ve geçicilik üzerine kurulu olan çalışma düzeninin insan karakterini, davranışlarını ve yaşama biçimlerinin nasıl dönüştüğünün ortaya çıkarılması için çalışılacaktır.

Sennett, öncelikle söz konusu olan değişimin belli anlamların dönüşmesi ile mümkün olabildiğini ifade etmiş, sözgelimi esnek kelimesinin vurgulanmasının bürokratik yapıların ortadan kaldırılması ile belirsizliğin hâkim hale gelmesinden kaynaklandığını belirtmiştir. Sennett'in $(2008,10)$ burada sorunlu olarak gördüğü konu ise bu belirsizliğin insanların gelecekle ilgili plan yapamama, bir hayat anlatısına sahip olamama durumuna yol açması ve bu belirsizliklerin insanlarda kaygı ve endişeye sebep olmasıdır.

Sennett, bugünün çalışma kültürü ile esnek üretimden önce yaygın olan çalışma kültürlerinin karşılaştırdığı eserinde 1970'li yıllarda çalışma hayatının içinde olan Enrico isimli temizlik görevlisi ile bugün üniversite mezunu ve iyi bir iş sahibi olan oğlu Rico'nun çalışma hayatında edinmiş oldukları deneyimleri karşılaştırmış ve esnek üretimle birlikte insanların hem çalışma hayatlarında hem de günlük yaşantılarında nasıl değişimler olduğunu gözler önüne sermiştir. Sennett'ın (2008, s. 14-15), bu karşılaştırmada üzerinde durduğu ve insanlar için ciddi bir anlamının olduğunu düşündüğü durum, bürokratik yapıların ortadan kalkmasının ve yeni zaman anlayışının, insanların belirsiz süreçlerin esiri olması ile 
kendilerine bir yaşam anlatısı yaratamıyor olmalarına yol açmasıdır. Bu şu anlama gelmektedir, Enrico, fiziksel olarak çok zor bir iş yapıyor, sınıfsal olarak en aşağı görülen konumda yer alıyor, yıllarca aynı işi yaparak geçimini sağlıyor olmasına rağmen, gelecekle ilgili bir öngörü sahibi olabilmesi mümkündü; çünkü hangi ay ne kadar kazanacağı, hatta emekli olduğunda yaşayacakları ile ilgili bir tahmini vardı ve bu tahmin çok yüksek ihtimalle gerçek olacaktı. Enrico'nun sahip olduğu yaşam öyküsünün ona güç verdiğini düşünen Sennett, çocukları için kurduğu planların onu yaşadığı hayattan tatmin olmasına yettiğini belirtmiștir.

Esneklik anlayışını, risk almayı, fırsatların peşinden koşmayı değerli gören, eski bürokratik yapıların insanları kendilerini geliştirmelerine engel olduğunu düşünen Rico'nun bu anlayışına rağmen kendi hayatları ile ilgili kontrol sağlayamadıkları için endişeli olduğunu; endişeye yol açan durumların ise görev tanımlamalarının belirsiz olmasından, belirli sözleşmeler dâhilinde çalışmaların sürdürülemediğinden, sürekli taşınmalarını gerektiren durumların söz konusu olmasından kaynaklandığı ifade edilmiştir (Sennett, 2008, s. 18).

Sennett'1 (2008, s. 19) Rico ile ilgili en çok şaşırtan ise iş hayatında yaşadığı olumsuzluklarla bir şekilde başa çıkabiliyor olmasına rağmen ailesi ve çevresi ile kurduğu ilişki ile ilgili endişe duyuyor olması ve çalışma hayatında başarı sağlayan davranışların gündelik yaşamlarında başarı sağlamıyor olduğunu düşünmesiydi. Çevresi ve daha da önemlisi ailesiyle kurmakta olduğu iletişimin Rico'nun istediği gibi olamaması, babası Enrico'ya benzer şekilde çocukları için iyi bir gelecek planlamak istemesine rağmen geleceklerini öngöremediğinden endişe içinde olduğu ifade edilmiştir.

Rico'nun çevresi ile kurmakta olduğu ilişkiden rahatsız olmakla birlikte çalışma hayatında sürdürmek zorunda oldukları alıșkanlıklarla ilgili sorun yaşamamasının, aksine rekabetin ve firsatların peşinden koşmanın anlamlı olduğunu düşünmesinin nedeninin daha çalışma hayatına başlamadan önce almış olduğu eğitim olduğu söylenebilir. Foucault'un iktidarla bireyler arasında kurulan ilişkiyi anlamlandırma biçimi bu sürecin anlaşılmasında önemli bir rol oynamaktadır. Foucault, (1992, 31-32), iktidar ilişkilerinin insan bedenine müdahale ve onu kontrol altında tutma eğiliminin sürdürülmek istenen düzene hizmet edecek şekilde düzenlendiğini ifade etmiştir. Bunun hayatın her alanında mümkün hale getirildiğini, daha çocukluktan başlanarak, okul gibi eğitim kurumları da kullanılarak bireylerin belli davranış ve anlayışları içselleştirmelerinin sağlanmaya çalışıldığını ifade etmiştir. Bedenin emek 
gücü olarak ortaya çıkmış olması kapitalist üretim sürecinin devamına hizmet edecek şekilde kontrol altına alınmak istenmesini de beraberinde getirmektedir. Bu nedenle baskı ve şiddet yoluyla çalışma koşullarının dayatılması değil; insanların yaşananları içselleştirerek, ona katılarak devamlılığın sağlanması durumu söz konusudur. Kathi Weeks (2014, s. 20) de benzer şekilde çalışma ile ilgili var olan düzenin ve kuralların sadece insanların ihtiyaç duyduklarını karşılamaya hizmet etmediğini, aynı zamanda bir kontrol mekanizması olarak ortaya çıktığını, toplumsal olarak bir uzlaşma sağlanmasına hizmet etmekte olduğunu ifade etmiştir. Bununla birlikte zaman geçtikçe sadece bedenlerin kontrol altına alınmasının da yeterli olmadığı görülecek ve tüketimin de kontrol altına alınması gerektiğinin farkına varılacaktı. Henry Ford'un fabrikasında çalışan işçiler için uyguladığı çalışma saati ve ücretleri onların tüketim alışkanlıklarının ve boş zamanlarının da denetlenmesi gerektiği anlayışına dayanıyordu, böylece fordist üretimle birlikte seri üretimle ortaya çıkarılan ürünlerin tüketicilerini bulmaları sağlanmıș oluyordu (Senemoğlu, 2017b, s. 67).

Esnekleşme anlayışının her geçen gün etkisini artırması ile içselleştirilen bireyselleşme anlayıșının sosyal ilișkilerin de zayıflamasına yol açtığı ortadadır, Rico'nun da bunu hissettiği için endişe ve kaygı içinde olduğundan söz eden Sennett (2008, s. 28), bu anlayışın beraberinde getirmiş olduğu dönüşümün sorumluluk bilinci ile ilgili olduğundan söz etmiş ve Rico'nun sürekli iş değiştirme deneyiminden yola çıkarak bu anlayışın nasıl deneyimlendiğini ortaya çıkarmaya çalıșmıştır. Sennett Rico'nun sıklıkla iş değiştirmek zorunda kalmasını kendi tercihi olarak yorumladığını, sosyal çevresi ile ilgili endişe duymasına rağmen kendisinden başka herhangi bir kişi ya da kurumu suçlama ihtiyac1 duymadığını fark etmiştir. Ayrıca insanların yaşadıkları başarısızlıklarla ilgili tüm sorumluluğu üstlendiklerini, sözgelimi işten çıkarıldıklarında kendilerini suçladıklarını ve bu durumun kendileri için endişe ve kaygı verici olduğunu, sosyal ilişkilerinin de bu durumdan etkilendiğini ifade etmiştir.

Daha önce de ifade edildiği gibi, yeni üretim süreci ve çalışma alışkanlıkları yeni anlamları da beraberinde getirmiştir; sözgelimi yetenek ile ilgili anlayışın ciddi bir değişim geçirmiş olduğu bilinmektedir. Zanaatkârlık anlayışının, bir şeyi iyi yapmak için çaba harcamanın fabrikada üretimin yaygınlaşması ile önemini kaybetmiş olduğu gibi, tecrübelerin, zaman geçtikçe edinilen deneyimlerin de değersizleştiği onun yerine yetenekle ilgili kriterlerin düzensizliklerle başa çıkma, her an her koşula uyum sağlama, belirsizlikleri avantaja 
çevirme olarak belirlendiği ve geçmişini terk edebilme, gelecekte yapılabileceklere odaklanmanın değerli görüldüğü bilinmektedir.

\section{Yeni Çalışma Anlayışının İnsanlara Hissettirdiği Duygular}

Gaulejac'in da ifade ettiği ve bu çalışmada da yer verilmiş olduğu gibi, esnek üretimde yaygın olan tavır, ekonomik bir savaşta olunduğu ve ortada bir felaket ya da çok kötü giden ekonomik koşullar olmadığında da endișe duyulmasıdır ve gelecekte ne olacağına dair herhangi bir bilgi sahibi olamamak insanlarda korku değil daha çok kaygıya yol açmaktadır. Esnek üretimle birlikte çalışma anlayışının endişe, kaygı ve stres yaratmakta olduğu bilinmektedir ve insanların bu durumla baș etme yöntemleri ile ișten çıkarıldıklarında geliştirdikleri tepkiler benzerlik göstermektedir; yaşamakta oldukları kaygı ve stresin kendileri tarafından başa çıkılması gereken bir sorun olduğunu düşünme eğiliminde oldukları görülmektedir. Bunun yanı sıra yeni çalışma anlayışının ve beraberinde getirmiş olduğu belirsizliğin strese yol açmakta olduğu gerçeğinin görmezden gelindiği ve neden ortaya çıktığının değil nasıl başa çıkılacağının önemsendiği ve hatta stresle başa çıkabilmenin bir başarı kriteri olarak görülmeye başlandığı bilinmektedir (Gaulejac, 2013, s. 192). Gaulejac (2013, s. 201), stresten kaynaklanan zihinsel hastalikların somut olarak çalışmanın sebep olduğu belirsizliklerden kaynaklandığını ispatlamanın zor olması nedeniyle tıpkı fiziksel rahatsızlıklar gibi tedavi edilmesi gereken ve bireylerin kendilerinin sorumluluklarında olan hastalıklar olarak görüldüğünü; fakat bu sorunun kişisel bir sorun değil, toplumsal bir sorun olduğunu belirtmiştir.

Sennett'e (2008, s. 146) göre sadece iş ile ilgili süreçlerin belirsiz olması, gelecekle ilgili plan yapılamaması, sürekli işsiz kalma endişesi ile yüz yüze olunması stres ve kaygıya yol açmamakta; işle ilgili pratiklerin sosyal yaşantılara yansımasından dolayı insanların birliktelik duygusu geliştirememeleri, içine düştükleri olumsuz durumlarla birlikte mücadele edecekleri kimsenin olmadığını hissetmeleri onların mücadele yöntemlerini ve topluma uyum süreçlerini etkilemektedir. Toplumsal yapıyı etkilemesi tam da bu sebeplerden mümkün olabilmektedir; çünkü esnek üretimle birlikte benimsenen, tek başına sorumluluk alma, geçmişini terk edebilme, geçmiş yeteneklere değil geleceğe odaklanma anlayışları insanların birbirleriyle kurmakta oldukları ilişkilerine de sirayet etmekte, dolayısıyla tüm yaşantılarının belirleyicisi olarak ortaya çıkmaktadır. Sözgelimi çalışma arkadaşları ile bir 
sorun yaşadığında sorunun çözümü için çaba harcamak yerine farklı bir iş bulmayı tercih eden ve yeni bir takımla çalışmayı sürdürebilen insanlar, aileleri ve çevreleri ile ilgili bir sorun yaşadıklarında da sorunun çözümü için çaba harcamak yerine gitmeyi tercih edebileceklerdir.

Esnek üretimle birlikte kabul gören insan ilişkilerinin aile içinde nasıl tecrübe edildiğine eğilen Standing (2017, s. 45), kurumların dönüşen yapısının devlet politikalarını da etkilediğini, devletin gerçekleștirmesi beklenen sosyal sorumluluklardan kaçmaya yönelik politikalar izlemesine karşılık insanların da sorumluluktan kaçmayı aile içindeki ilişkilerin en aza indirmeyi tercih ettiklerini ifade etmiştir. Esasen bu durumu yardımlaşmanın ve başkası ile ilgili sorumluluk almanın kötü bir durum olarak algılanmasının toplumsal bir yansıması olduğunu söylemek mümkündür, esnek üretimle birlikte daha fazla hissedilmeye başlanan bireysellik anlayışı, herkesin sadece kendisinden sorumlu olması anlayışının kabul görmesine yol açmaktadır. Herkes tarafından kabul görülüyor olmasına rağmen bir anlayışın insanlara zarar vermekte olduğunu söylemek çok kolay olmadığı gibi, yaşanan ilişkilerdeki yüzeyselliğin ve geçiciliğin bu durumun kanıtı olarak gösterilebileceği düşünülmektedir. $\mathrm{Bu}$ konu ile dikkat edilmesi gereken bir diğer nokta ise insanların yardımlaşma, başkası için sorumluluk almak için genellikle zaman ve imkân bulamadıklarını göz ardı etmemek gerektiğidir, performansa dayalı emek sürecinin insanları çok çalışmaya mahkûm ettiğini ve bunun dışında herhangi bir faaliyet için zaman bulunamadığını tahmin etmek zor değildir.

İnsanların yardımlaşmadan kaçındıkları, sadece kendilerini önemsediklerini düşündürtebilecek olan bu durumda göz ardı edilmemesi gereken nokta, Hobbes'un insan doğasına dair yaptığı açıklamalarla da desteklenebileceği gibi, insanların her durumda kötülük yapma eğiliminde olduğu değil, içinde bulunduğu şartların, uyum sağlamak zorunda olduğu yaşam biçimlerinin kötülük yapmalarına yol açabilecek olmasıdır (Senemoğlu, 2016, s. 91).

Dolayısıyla insanların birbirlerine yardım etmekten kaçınıyor olmalarının sebeplerinden biri esnek üretimin yol açtığı güvensizliktir, yeni ekonomik düzenin insanların değerli bir şey yaptıklarını hissetmelerine engel olması ile birlikte yerlerinin kısa sürede doldurabileceği hissi kendilerinin değersiz, hemen vazgeçilebilen insanlar olduklarını düşünmelerine yol açabilmektedir. $\mathrm{Bu}$ nedenle de fazladan sorumluluk almanın, kendi durumlarının ne olacağını tahmin edemedikleri düzende bir de yardım etmek için fazladan çaba harcamanın 
kolay olmayacağını söylemek yanlış olmayacaktır. Sennett (2008, s. 154), bu durumun esnek üretimle birlikte hissedilmeye başlanan bir duygu olmamakla birlikte, esnek üretimin bunu daha hissedilir hale getirdiğini, işe yaramazlık duygusunun sadece maddi koşullara bağlı olarak hissedilemediğini, çalışma düzeninin insanları değersiz hissetmelerine yol açarak bir ikna ve rıza mekanizması sağlandığını belirtmiştir. Enrico'nun çalışma hayatının zorluklarla dolu olması ile birlikte devam eden bir yaşam anlatısının, çocukları için iyi bir şey yapıyor olduğunu hissetmesinin ona sağladığı avantaja karşılık Rico'nun da ailesini önemsemesine, çocuklarına maddi olarak iyi imkanlar sağlayabiliyor olmasına rağmen ailesi için iyi şeyler yapmakta olduğunu hissedemiyor olmasının esnek üretimin örgütlü kapitalizmden farklı olarak işe yaramazlık hissine yol açmasından kaynaklandığını söylemek yanlış olmayacaktır.

Modern zamanlarda ortaya çıkan ihtiyaçlardan birinin bir kimliğe sahip olmak olduğu, verili olmayan kimliğin inşasının insanların kendi sorumluluklarında olduğu bilinmektedir ve kimlik inşa sürecinde kapitalist kültürün egemen hale gelmesiyle zenginlik ve statünün ön plana çıkmış olduğu bilinmektedir (Bauman, 2005, s. 178). İnsanların meslekleriyle bir kimlik sahibi olmaları şaşırtıcı olmamakla, hatta zanaatkârlıkta kıymetli görülen bir anlayış olmakla birlikte bugün muğlaklaşan ve geçicileşen meslek anlayışında bu durumun sorun yaratabileceği söylenebilir. Mesleğin prestij sağlamada bu kadar önemli hale gelmesi ile sürekli iş değiştirmek zorunda kalan, kalıcı ve kendilerine prestij sağlamayan işlerde çalışmak zorunda olan insanların kendilerini değersiz hissettikleri, diğer taraftan kendilerine prestij sağlayan işlerde çalışan insanların da işlerini kaybetmekten sadece maddi açıdan zorluk çekebilecekleri için değil başarısız hissedecekleri için endişe duydukları görülmektedir.

Bunların yanı sıra bu durum insanların gelecekleri ile ilgili endişe duymalarına yol açmakta, hayatlarında yeni bir baskı unsuru olarak ortaya çıkmaktadır. Çeşitli meslek gruplarıyla yaptığı görüşmelerden edindiği deneyimlerini paylaşan Botton'ın (2014, s. 116) yer vermiş olduğu örneklerden biri bu durumu açıklar niteliktedir; kariyer danışmanı olarak çalışan kişinin insanların en çok endişe ettikleri konunun daha çalışma hayatının başında meslek seçiminde doğru karar veremeyecekleri ile ilgili olduğunu dile getirmiştir. İnsanların seçecekleri mesleklerle ilgili endişe duymaları anlamsız görünmemektedir, burada sorunlu olan konu, insanların yeteneklerine ve ilgilerine göre meslek seçmeye çalışmaktansa hangi mesleğin kendilerine prestij sağlayacağına odaklanmış olmalarıdır; fakat bunun için bireysel 
olarak insanların suçlanması anlamlı görünmemektedir, mesleğin kimlik haline gelmesinin, insanların toplum tarafından nasıl göründüklerinin mesleklerine bağlı olmasının insanları bu duruma sürüklediği açıktır.

Bunun yanı sıra Botton (2005, s. 15), statü, prestij sahibi olmanın insanlar için önemli olmasının sebebinin kabul görmek, sevilmek, önemsenmek gibi duyguların tatmin edilmesine hizmet etmesinden kaynaklandığını düşünmektedir. Benzer şekilde Polanyi (2010, s. 88-89) de ekonomik süreçlerin sosyal ilişkiler üzerinde ciddi bir rol oynamakta olduğunu düşünmekte, insanların maddi zenginlik için çaba göstermelerinin sebebinin toplumsal olarak bir konum sahibi olma ve sosyal çevrelerinden değer görme ihtiyacından kaynaklandığını savunmaktadır.

Toplumsal süreçleri ekonomik süreçlerden ayrı yorumlamak mümkün görünmemektedir; insanların yaşadıkları başarısızlıklarla ilgili sorumluluk almak zorunda olmaları, statünün insanın değerli görülmesinde önemli rol oynuyor olması kapitalist kültürün zenginliği ve daha fazla kâr elde etmeyi hedefliyor olmasından kaynaklanmakta ve bu anlayış toplumsal yaşayışı da şekillendirmektedir. Dolayısıyla şunu söylemek mümkündür ki, fabrikada çalıșan işçiler, kamu kurumlarında istihdam edilen memurlar, esnek üretimle birlikte yaygınlaşan hizmet sektöründe çalışan insanlar sadece ürün ya da hizmet üretmiş olmakla kalmaz aynı zamanda toplumsal ilişkileri de üretmiş olurlar (G. Özdemir \& A. Özdemir, 2008, s. 51).

Esnek üretimle birlikte bu durumun nasıl tecrübe edildiğine değinen Gaulejac (2013, s. 156), bireylerin yaşamlarının işletmecisi haline geldiğini, kendisine prestij sağlayacak bir iş sahibi olmak için hedef belirlemesi, bu hedefe göre tüm hayatını ve zamanını düzenlemesi, performansını her gün artırmak üzere çalışma hayatında yer alması gerektiğini ifade etmiştir. Sennett'in (2008, s. 87-88) uzun yıllar bar işletmeciliği yapan Rose'un deneyimlerinin değerli olacağına güvenerek çalışmaya başladığı reklam şirketinde yaşadıkları bu duruma örnek olarak gösterilebilir. Rose'un her an işten çıkarılma korkusu ile karşı karşıya kalmış olduğunu aktaran Sennett, orada kalmaya devam ettiği her gün kendini kanıtlamak zorunda kaldığını, yeni bir şeyler, kendini ön plana çıkaracak işler ortaya çıkarmadığında önceki başarılarının da görmezden gelindiğini ve bu şekilde davranmadığı sürece işten çıkartılacağını bildiğini dolayısıyla bunun risk ile yaşamayı öğrenmek olarak nitelendirilebileceğini ifade etmiştir. Esnek üretim anlayışı ile birlikte insanların hayatlarını 
sürekli risk altındaymış gibi yaşamak zorunda kaldıkları, olumsuz bir durum olmadığında dahi endişe ve kaygı hissettikleri görülmektedir.

\section{Türkiye'de Esnek Üretim Süreçlerinin Deneyimlenmesi}

Sennett'ın esnek üretimle birlikte ortaya çıktığını ileri sürdüğg̈ dönüşümlerin izlerini Türkiye'de sürmek de mümkündür. Esnek üretim anlayışının yol açtı̆̆ı dönüşümden hayatlarını devam ettirmek için çalışmak zorunda olan tüm insanların etkilenmekte oldukları görülmektedir. Türkiye'de de Sennett tarafından dile getirilen vasıfsızlaştırma, güvencesizlik, deneyimlerin değersizleşmesi, insanların yaptıkları işlerle, çalıştıkları kurumlarla ve bir arada çalışmakta oldukları insanlarla bağ kuramaz hale gelmeleri gibi sonuçlarla karşılaşılmaktadır. Burada söz konusu edilen durumlardan bazılarına örnek olarak gösterilebilecek çalışmalara yer vermek Türkiye'de yeni çalışma anlayışının çalışanlar tarafından nasıl deneyimlendiğinin ortaya çıkarılması açısından önemli görünmektedir.

Söz gelimi Ebru Ișıklı'nın yönetim kadrosu dışındaki ofiss çalışanları ile yapmış olduğu mülakatlara dayanan çalışması, ofis çalışanlarının yaşanan dönüşümü nasıl tecrübe ettiklerinin anlaşılması açısından değerlidir. Çalışmada mülakatlardan edinilmiş olan ilk izlenim, Sennett'ın sıklıkla vurgulamıș olduğu gibi esnek üretimle birlikte dönüșen otoritenin tüm sorumluluğu çalışanlara yüklediğidir. Ofis çalışanlarının işlerini tamamlamak üzere fazla mesai yaptıklarında bunun için ücret talep etmekten çekinmeleri ve işlerini tamamlamalarının kendi sorumluluklarında olduğunu ifade etmeleri, buna hakları olmadığına inandırılmış olmaları yapılan işlerin tüm sorumluluğunu almak zorunda olduklarını gösterir niteliktedir (Işıklı, 2013, s.196-197). Bu örnekten yola çıkarak işin nasıl tamamlandığı ile ilgilenmeyerek sonuca odaklanan, dolayısıyla tüm sorumluluğu çalışana yükleyen yeni çalışma anlayışının insanlara ciddi sorumluluklar yüklemekle birlikte insanları hak ettiklerini talep etmekten dahi mahrum bırakmakta olduğunu ve insanların kendilerine olan güvenlerini de kaybetmelerine yol açacağını söylemek yanlış olmayacaktır. Esnek üretim süreçleri ile birlikte başarının ilk koşulunun geçmişini terk edebilme, her türlü ortama uyum sağlayabilme ve her işin üstesinden gelebilme ile özdeşleştirilir hale geldiği görülmektedir. Sennett, bu durumun insanların işleri ile kurdukları bağın daha da muğlaklaşmasına yol açmakta olduğunu düşünmektedir; çünkü sıklıkla iş değiştirmek zorunda olan insan her seferinde hayatını yeniden kurmak zorunda kalacak ve yaşadıklarına 
yabancılaşacaktır. Türkiye' de de benzer anlayışın gelişmiş olduğunun ortaya çıkarılabilmesi için başarılı bir iş görüşmesinde yapılması gerekenlerle ilgili kriterlere göz atmak yeterli olacaktır. Son yıllarda iş görüşmesi ile ilgili tavsiyelerin insanların geçmiş tecrübeleri ve yetenekleri ile ilgili olmaktan ziyade dış görünüşleri, her işi rahatlıkla yapabileceklerine dair istekli olmaları ile ilgili olduğu, dolayısıyla mesleki yetenek ve tecrübelerin ikinci planda kaldığı, sosyal becerilerin, rekabet ortamında ayakta kalabilecek olmanın ön plana çıkarılmakta olduğu görülmektedir (Bora, 2017, s.63). Buradan çıkarılabilecek sonuç, sahip olunan yeteneklerin, deneyimlerin değersizleştirilmiş olduğu ve bir alanda uzmanlaşmış olmaktansa vasıfsız olmanın daha tercih edilir olduğudur. Böylece sürekli değișen piyasa koşullarına göre insanların yaptıkları işlerin değiştirilmesi mümkün olabilecek, iş sahibi olan insanlar aynı kurum içinde dahi farklı görevler üstlenebileceklerdir.

Tanıl Bora (2017, s.58) Türkiye'de tüm sektörlerde çalışan insanların üretim süreçlerinin esnetilmesi anlayışından etkilenmekte olduğunu ortaya çıkarmayı amaçlamış olduğu makalesinde beyaz yakalı çalışanlar tarafından güvencesizleşme ve geçici sözleşmelerle çalışma anlayışının nasıl deneyimlenmekte olduğunu aktarmıştır. Görüşmeler yaptığı kişilerden biri olan inşaat mühendisin yaşadığı deneyimlerden yola çıkarak çalışma süreçleri ile ilgili yaşananlara 1şık tutmaya çalışmıştır. Makalede yeni mezun bir inşaat mühendisi olan görüşmecinin kısa süreli sözleşmelerle istihdamın yaygınlaşmış olduğu inşaat sektöründe özellikle yeni mezunların çok düşük ücretlerle çalışmayı kabul ettiklerinden koşulların iyice kötüleşmiş olduğunu belirttiğine yer vermiștir. Yeni mezunların bu durum karşısında nasıl bir tavır almaları gerektiğini bilemediklerinden bu durumu kabullenmiş olduklarını, kısa süreli çalışmayı daha iyi işlerde çalışmaya başlamadan önceki adım olarak gördüklerinden sorun haline getirmediklerini, sürekli daha iyi fırsatlar peşinde koştuklarını ve sıklıkla iş değiştirdiklerini ifade ettiğini eklemiştir. Burada sorun olarak görülecek durumlardan ilki genç mühendislerin zaman geçtikçe yaşayacakları hayal kırıklığıdır; çünkü esnek üretimin güvencesiz çalışma anlayışı tüm hayatları boyunca kendilerini etkileyecektir. Kalıcı olacak bir işte çalışma ihtimalleri düşük olduğundan gelecekle ilgili kendilerine bir yol çizme konusunda ciddi problemler yaşayacaklarını tahmin etmek zor değildir. Bunun yanı sıra bu olayın işaret ettiği bir diğer durum ise sadece mavi yakalıların değil esnek üretim anlayışının etkisini artırdığı güvencesiz çalışma anlayışının tüm çalışma alanlarında etkisini göstermekte ve insanları bu şartlarda ayakta kalmaya zorlamakta olmasıdır. 
Türkiye'de esnek üretim anlayışının sadece özel kurumlarda çalışan insanların hayatını etkilemediği, esnekleşme anlayışının kamu kurumlarında da etkisini gösterdiği ve uzun yıllar aynı yerde çalışma anlayışının gün geçtikçe etkisini yitirdiği bilinmektedir. Devlet okullarında ücretli ya da sözleşmeli öğretmenlerin istihdam edilmesi, kamu kurumlarında taşeron firmalar aracılığıyla görev almakta olan çalışanlar bu duruma örnek olarak gösterilebilir. Türkiye'de 4A güvenceli memurluk kadrolarının yerini özel meslek bilgisi gerektiren durumlar için uygulanan 4B kadrosu ile istihdama birakmakta olduğu görülmektedir. 4B kadrosu ile ilgili vurgulanmak istenen esnek üretim anlayışına uygun olarak düzenlenmiş bu kadronun güvencesiz ve iş garantisi olmayan bir kadro olması ve kısa süreli sözleşmelerle istihdamı kolaylaştırmakta olmasıdır (Kablay, 2014, s.176-177). Aynı kurumda benzer görevlerde yer almalarına rağmen geçici kadro ile çalışan insanların birlikte çalıştıkları insanlarla aynı haklara sahip olmamaları insanlar arasında statü farkının adaletsiz bir şekilde ortaya çıkmasına yol açmakta ve insanlar arasındaki rekabeti daha da kızıştırmaktadır. Bunların yanı sıra çalıştıkları kurumlardan her an ayrılma riski ile yaşamak zorunda olan insanların birlikte çalıştıkları insanlarla ve yaptıkları işlerle bağ kurmalarının mümkün olamayacağı açıktır.

Aynı şekilde devlet okullarındaki öğretmen ihtiyacının büyük bir kısmının sözleşmeli ya da ücretli öğretmenlik kadroları ile sağlandığı görülmektedir. Aynı işi yaptıkları halde kadrolu öğretmenlerle aynı haklara sahip olamayan geçici statüdeki öğretmenlerin sayısının gün geçtikçe artmakta olduğu görülmektedir. 2000'li y1lların başından itibaren uygulanan yöntem ile üniversitede öğretmenlik eğitimini tamamladıktan sonra kadrolu olarak öğretmenlik görevine gelebilmek Kamu Personeli Seçme Sınavı (KPSS) sonuçlarına bağlı olduğundan geçici ve sözleşmeli öğretmenlik anlayışının kabul görür hale geldiği bilinmektedir. Böylece insanlar sınavlardan başarısız oldukları için kadrolu olarak mesleklerini icra edemeyeceklerini düşünmek zorunda bırakılmaktadırlar (Ertürk, 2013, s.123). Türkiye'de yaşanan bu durum Sennett'ın sözünü ettiği, otoritenin emek süreçlerinin sorunsuz bir şekilde sürdürülmesi için belli kriterler ortaya çıkarmasına örnek olarak gösterilebilir. Belli kriterleri sağlayamayanlar başarısız olarak nitelendirilecek ve insanlar bu başarısızlıkla tek başlarına mücadele etmek zorunda olduklarını kabul etmek zorunda kalacaklardır. Böylece sınavda başarılı olamadığı için geçici öğretmenlik kadrolarında çalışmayı kabul etmek zorunda kalan insanlar yaşadıklarını bir haksızlık olarak görmeyecek, görseler bile nasıl mücadele edeceklerini bilemeyecek ve sistemin sorunsuz bir şekilde 
devam ettirilmesi mümkün olacaktır. Bu nedenle insanların yaşadıkları ile ilgili sorumluluk almaları, içine düştükleri durumlarla tek başlarına mücadele etmek zorunda hissetmeleri esnek üretim anlayışını sürdürülmesi açısından önemlidir ve Sennett bu durumun görmezden gelindiği için üzerinde durulmasının önemli olduğunu vurgulamaktadır.

Türkiye'de esnek üretim anlayışının egemen hale gelmesi ile en çok etkilendiği bilinen insanlar hizmet sektöründe çalışanlardır; çünkü esnek üretimle birlikte esnek çalışma saatleri ve insanlara yüklenen sorumlulukların artırılmasına fırsat yaratıldığı bilinmektedir. Bunun yanı sıra hizmet sektöründe çalışan insanların fiziksel olarak zor şartlara maruz kalmaları ile birlikte müşterinin memnun edilmesine dayanan çalışma biçiminin insanların yapmakta oldukları işlerle bağ kurmada daha ciddi sorunlar yaşamalarına yol açmaktadır. Bu durum otel, çağrı merkezi ve bir satış mağazası çalışanları ile yapılan görüşmelere dayanan çalışma örnek olarak gösterilerek daha açık bir şekilde ifade edilebilecektir. Yapılan çalışmada ortaya çıkan sonuç, hizmet sektöründe çalışan insanların fiziksel olarak yıpranmalarının yanı sıra duygusal olarak da yıprandıklarıdır; çünkü müşterileri memnun etmek zorunda olduklarından kendi gerçeklerini, hissettiklerini ve doğrularını bir tarafa bırakmak zorunda kalan insanlar yaptıkları işlere iyice yabancılaşmışlardır (Kaya, Serçeoğlu, 2013, s.317-318). Müşterilerin memnuniyeti için çalışanlarından çaba beklemesi, şirketlerin kârlarına odaklanmış olmaları şaşırtıcı değildir. Burada vurgulanmak istenen esnek üretim süreçleri ile bu durumun daha şiddetli bir şekilde hissedilmeye başlanması, çalışanlarının fiziksel ve ruhsal durumlarının göz ardı edilerek sadece kendi çıkarına odaklanmış kurum sahiplerinin keyfi davranışlarına firsat yaratılmış olmasıdır. Elbette işverenlerin çalışanların ihtiyaçlarını ve isteklerini görmezden gelmeleri esnek üretimle birlikte ortaya çıkmış değildir; burada çalışma ile ilgili tüm süreçlerin belirsizleşmiş olduğundan yaşanan sömürü ve tahribatın daha ağır olduğu vurgulanmak istenmektedir. Kısa süreli, güvencesiz bir şekilde istihdamı kolaylaştırılmış olması nedeniyle işverenler durumundan şikayetçi olacak çalışanı kolaylıkla işten çıkartabilecek ve yerine kolaylıkla başka birini getirebilecektir. Bu durumun insanların kendilerine olan güvenlerini de kaybetmelerine yol açmakta olduğu açıktır, yerinin kolaylıkla doldurulabileceğini ve işten çıkarılmasının hiç de zor olmadığını bilen insan bir iş sahibi olduğunda dahi kendini güvende hissedemeyecek ve gelecekle ilgili endişe içinde hayatını sürdürmek zorunda kalacaktır.

Türkiye'de geçici sürelerle çalışma anlayışının benimsenmiş olduğuna örnek olarak gösterilebilecek olaylardan biri de kısa süreli projelerde istihdam edilme eğilimidir. Parça 
başı iş anlayışının modern biçimi olarak görülebilecek olan projelerde istihdam edilmenin özellikle beyaz yakalı çalışanlar tarafından tercih edilir olduğu görülmektedir (Bora, 2017, 215-216). Düzensiz ve garantisiz iş imkânı olarak nitelendirilebilecek bu çalışma anlayışının insanların geleceklerini planlayabilmelerine engel olmasına rağmen tercih edilmesinin birçok sebebi olmakla birlikte bu çalışma açısından önemli görülebilecek sebebi tüm kurumların güvencesizleştirilmiş olmasından dolayı insanların kendilerini çaresiz hissetmeleri ve yeni firsatların peşinden koşabilmek için projelerde çalışmanın kendilerine avantaj sağlayabileceğine inandırılmış olmalarıdır.

Söz konusu örneklerle işaret edilmek istenen Sennett'ın esnek çalışma anlayışının yol açtığını düşündüğü güvensizlik, belirsizlik ve insanların hayatlarını endişe içinde sürdürdüklerine dair endişelerinde haklı olduğu ve Türkiye'de de benzer süreçlerin yaşanmakta olduğudur. Geçici sözleşmelerle, kısa süreli işlerde, haklarını alamayan insanların gelecekleri ile ilgili endişe içinde hayatlarını sürdürmek zorunda oldukları görülmektedir. Her an işsiz kalabileceği gerçeği ile yüz yüze olan insanlardan işin kendilerine yüklediği sorumluluklarla mücadele ederken aynı zamanda yeni bir iş bulmak için hazırlıklı olmaları beklenmektedir. Bunlarla birlikte tüm süreçlerin esnetilmiş olduğu çalışma anlayışı ile yaptıkları işleri kendilerince anlamlı hale getirmekten de mahrum kalmış insanların ayakta kalmakta zorlandıklarını tahmin etmek zor değildir.

\section{Sonuç}

Sennett'ın kaleme almış olduğu eserlerinin değerli görülmesi ve bu çalışmanın ortaya çıkmasının sebebi esnek üretimle birlikte çalışma ile ilgili yaşanan dönüşümün Türkiye'de de benzer şekillerde yaşanıyor olmasındandır. Bununla birlikte Sennett'ın literatüre yapmış olduğu düşünülen katkısı ise insanların çalışma ile ilgili yaşamakta oldukları sorunların çözümüne ilişkin getirilen yorumlardan farklı olarak Sennett'ın bu sorunların nedenlerine dair anlaşılır bir tablo çiziyor olmasıdır. Zanaatkârlığın terk edilmesi ile insanların yaptıkları işleri anlamlandırmakta zorlanmalarının, iş birliği ve rekabet anlayışının dönüşmesi ile insanların içine düşmüş oldukları yalnızlık ve güvensizliğin nasıl ortaya çıkmakta olduğunun anlaşılması için ortaya koyduğu çabanın değerli olduğu düşünülmektedir.

Kapitalist kültürün insanların yaşamlarında nasıl bir tahribata yol açtığını gözler önüne sermek isteyen Sennett, söz konusu etmiş olduğu olumsuz etkilerin esnek üretimle birlikte 
ortaya çıkmış olduğunu savunmamakta; fakat esnek üretimle birlikte ortaya çıkan belirsizliklerin insanlarda daha ciddi tahribatlara yol açtığını vurgulamaktadır. Öncelikli olarak zanaatkârlık anlayışının fabrikada üretimin yaygınlaşması ile terk edilmesinin etkilerinin bugün dahi sürdügünü, üretim biçimi olarak sürdürülmesinin mümkün olmamas1 ile birlikte hiç olmazsa bu anlayıșın düşünce olarak etkisinin devam ettirmesinin çok değerli olacağını düşünmekle birlikte bunun mümkün olmadığını gözler önüne sermiştir.

Sennett bir şeyi en iyi şekilde yapmak için çaba harcayan kişi olarak tarif ettiği zanaatkârın yani ürünün hangi adımlardan geçerek ortaya çıktığını, yapım aşamasında nelerle karşılaşıldığını ve hepsinden önemlisi ürünün insanlara sağlayacağı fayda ile ilgili anlamlı bir ilişki kurabilen kişi olduğunu ifade etmiştir. Bunun aksine esnek üretimle birlikte sözgelimi yaptığı ekmeğin sadece bir tuşa basmaktan ibaret olduğu günün koşullarında çalışan insanın bu ilişkiyi kurabilmesini beklemenin anlamlı olmadığını ortaya çıkarmayı amaçlamaktadır. Elbette teknolojinin gelişimi ile bazı adımların daha hızlı bir şekilde gerçekleştirilmesi insanların fiziksel olarak daha iyi şartlarda çalışmalarına imkân sağlamaktadır; Boston'daki üretim sürecini yirmi beş yıl ara ile gözlemlemiş olan Sennett bu duruma şahit olmuştur; fakat tüm bu olanakların yanında insanların gerçekleştirmekte oldukları faaliyetlerden daha da uzaklaştıkları görülmektedir ve Sennett bu durumun insanların tüm sosyal ilişkilerine yansıyor olmasından dolayı endişe verici olduğunu düşünmektedir.

Zanaatkârlığın etkisini yitirmesinin yeni yetenek kriterlerinin ortaya çıkmasına yol açtığını ifade eden Sennett, günün iş gücü ihtiyacına göre belli kriterlerin ortaya çıtığını, bu kriterlerin belli gruplar tarafından belirlendiğini ve diğer tüm insanların bunlara uyacak şekilde bir yaşam tarzı kurmak zorunda kaldıklarını ortaya çıkarmayı amaçlamaktadır. Bu durumun yol açtığı sorun sadece insanların bu kriterlere boyun eğmek zorunda kalmaları da değildir, aynı zamanda belirli kriterleri sağlayamayanların başarısız olarak nitelendirilmeleri ve somut bir gösterenle işaret edilen başarısızlığın insanların kendi sorumluluklarında olduğunun savunulmasıdır. Esnek üretimin yaygınlaşması ile hissedilen en ciddi durumlardan birinin insanların yaşadıklarından tek başlarına sorumlu olmalarını gerekli gören anlayış olduğunu söylemek yanlış olmayacaktır. İnsanları yalnızlaştıran, yaşadıkları sorunlarla ilgili mücadele yöntemlerinin bertaraf edilmesine yol açan bu anlayışın ortaya çıkmasındaki en önemli etkenin kurumların yapısal olarak geçirdikleri dönüşümler olduğunu söylemek mümkündür. 
Kurumsal yapılarda ortaya çıkan değişimin en temel sebebi, hızlı bir şekilde değişim gösteren piyasa koşullarına cevap verebilmekti ve kurumsal yapının esnetilmesi olarak ortaya çıkan bu durum ara katmanlı yapının yerini işin tamamlanması için belirlenen adımların işi kısa sürede tamamlamaya ve daha hızlı karar almaya odaklanmış anlayışa bırakmasıydı. Sennett'in deyimiyle günün kısa vade anlayışına uygun olarak düzenlenen kurumsal yapının mesleklerin muğlaklaşmasına, iş sözleşmelerinin geçicileşmesine, güvencesiz çalışma anlayışının yaygınlaşmasına yol açtığı bilinmektedir. Sennett'e göre, esnek kurumsallaşmanın yol açtığı en ciddi sorun kısa süreli iş sözleşmeleri ve geçici istihdamın yol açtığı insanların gelecekle ilgili öngörü sahibi olamamaları ve buna bağlı olarak da bir yaşam anlatısından mahrum olmalarıdır. İnsanlar esnek üretimin yol açtığ uzun saatler çalışma ve fazla iş yükünün yanı sıra bir de geleceğin belirsizliği ile başa çıkmak zorunda kalmaktadırlar.

Bununla birlikte bu belirsizliklere rağmen ayakta kalmanın bir kriter olarak ortaya çıktığına değinen Sennett, çalışanlar açısından bu durumun nasıl tecrübe edildiğine eğilmenin önemli olduğunu vurgulamış ve yaptığı gözlemler 1şığında çalışma ile ilgili kavramların dönüşmüş olduğunu rekabet ve iş birliği anlayışlarının tüm sorumluluğu çalışanlara yükleyecek şekilde düzenlenmiş olduğunu ifade etmiştir. Hali hazırda güvencesiz çalışma anlayışının insanlara yüklemiş olduğu belirsizliklerle birlikte uzun süre bir arada çalışmanın sağladığı güven duygusundan da mahrum olan insanların yeni çalışma anlayışı ile daha ciddi baskılara maruz kaldıklarını vurgulamıştır.

Sennett'ın esnek üretim anlayışının yol açtığını düşündüğü sorunlardan bir diğeri ise çalışma hayatında ayakta kalmak için edinilen alışkanlıkların sözgelimi kısa vadeli amaçlara yönelmenin, geçmişini geride bırakabilmenin toplumsal hayata da yön veriyor olması ve insanların tüm ilişkilerinde bu alışkanlıkların sürdürülmesidir. Bunun bir iktidar biçimi olarak ortaya çıktığı, insanların ekonomik düzene uyum sağlamaları amacına hizmet ettiği, bunun sadece çalışma ile ilgili alanlarda değil hayatın her alanına yansıtılarak mümkün olabileceği için tüm kurumların buna göre dönüşmüş olduğu görülmektedir.

Sennett, yaşanan tüm bu dönüşümün insanlardaki karş1lığının ise stres, kaygı ve işe yaramazlık endişesi ile hayatlarının sürdürülmesi olduğunu ifade etmektedir. Çalıştığı kuruma karşı sadakat ve bağlılık hissedemeyen, bir arada çalıştığı iş arkadaşlarına güvenemeyen, edinmiş olduğu kabiliyetler değersizleşeceği için endişe duyan, gelecekle 
ilgili plan yapamayan insanın hayatını stres ve kaygı içinde sürdürmekte olması şaşırtıcı değildir. Bunların yanı sıra mesele sadece işsiz kalma endişesi de değildir, yapılmakta olan işin bir kimlik olarak ortaya çıkması da insanları statü ve prestij peşinde koşmaya zorlamakta, insanların becerilerine, ilgilerine göre meslekler seçmektense kendilerine prestij sağlayacağını düşündükleri işlerde çalışmak için kendilerine yol çizdikleri görülmekte ve bunun sonucunda da yaptıkları işlerle bağ kurmalarının iyice zorlaştığı bilinmektedir.

\section{KAYNAKCA}

Bauman, Z. (2005). Bireyselleşmiş Toplum (çev. Yavuz Alogan). İstanbul: Ayrıntı Yayınlar1

Beaud, M. (2003). Kapitalizmin Tarihi (çev. Fikret Başkaya). Ankara: Dost Kitabevi

Bora, T. (2017). Herkes İșsiz Ama Seninki Farklı: Türkiye’de Beyaz Yakalı İșsizliğine Genel Bir Bakış. Tanıl Bora, Aksu Bora, Necmi Erdoğan, İlknur Üstün (Ed.), Boşuna mı Okuduk? Türkiye'de Beyaz Yaka İșsizliği (6. Baskı) içinde (s. 49-71). İstanbul: İletişim Yayınları

Bora, T. (2017). Beyaz Yakalıların İş Bulma ve Geçinme Stratejileri. Tanıl Bora, Aksu Bora, Necmi Erdoğan, İlknur Üstün (Ed.), Boşuna mı Okuduk? Türkiye'de Beyaz Yaka İşsizliği (6. Baskı) içinde (s. 203-258). İstanbul: İletişim Yayınları

Botton, A. (2005). Statü Endişesi (çev. Ahu Sıla Bayer). İstanbul: Sel Yayınları

Botton, A. (2014). Çalışmanın Mutluluğu ve Sıkıntısı (5.bs.) (çev. Süha Sertabiboğlu). İstanbul: Sel Yayınları

Dowd, D. (2013). Kapitalizm ve Kapitalizmin İktisadı: Eleştirel Bir Tarih (2. bs.) (çev. Cihan Gerçek). İstanbul: Yordam Kitap

Duhm, D. (2015). Kapitalizmde Korku (2. bs.) (çev. Sargut Şölçün). İstanbul: Kırmızı Yayınları 
Ertürk, E. (2013). Türkiye'de Öğretmenlik Mesleğinin Dönüşümü. Ayşe Buğra (der.), Sınıftan Sınıfa: Fabrika Dışında Çalışma Manzaraları (2. baskı) içinde (s. 113-148). İstanbul: İletişim Yayınları

Foucault, M. (1992). Hapishanenin Doğuşu (çev. Mehmet Ali Kılıçbay). Ankara: İmge Kitabevi

Fromm, E. (1996). Çağdaş Toplumların Geleceği (çev. Gülnur Kaya-Kaan H. Ökten). İstanbul: Arıtan Yayınevi

Gaulejac, V. (2013). İşletme Hastalığın Tutulmuş Toplum (çev. Özge Erbek). İstanbul: Ayrıntı Yayınları

Gorz, A. (2014). Yaşadığımız Sefalet: Kurtuluş Çareleri (2. bs.) (çev. Nilgün Tutal). İstanbul: Ayrıntı Yayınları

Harvey, D. (2010). Postmodernliğin Durumu: Kültürel Değişimin Kökenleri (5. bs.) (çev. Sungur Savran). İstanbul: Metis Yayınları

Harvey, D. (2015). Neoliberalizmin Kısa Tarihi (2. bs.) (çev. Aylin Onacak). İstanbul: Sel Yayınc1lık

Hobsbawm, E. (2003). Sanayi ve İmparatorluk (2. bs.) (çev. Abdullah Ersoy). Ankara: Dost Kitabevi

Işıklı, E. (2013). Ofis Çalışanlarının Yalnızlığı. Ayşe Buğra (der.), Sınıftan Sınıfa: Fabrika Dışında Çalışma Manzaraları (2. baskı) içinde (s. 181-208). İstanbul: İletişim Yayınları Kablay, S. (2014). Kamu İstihdamındaki Esnekleșmeye 4B Örneğinden Bakış. Özgür Müftüoğlu, Arif Koşar (haz.), Türkiye'de Esnek Çalışma içinde (s. 158-184). İstanbul: Evrensel Basım Yayın

Kaya, U. ve Serçeoğlu, N. (2013). Duygu İşçilerinde İşe Yabancılaşma: Hizmet Sektöründe Bir Araştırma. Çalışma ve Toplum Ekonomi ve Hukuk Dergisi, 1(36), 311-346. Macfarlane, A. (1993) Kapitalizm Kültürü (çev. Remzi Hakan Kır) İstanbul: Ayrıntı 
Yayınları

Polanyi, K. (2010). Büyük Dönüşüm: Çağımızın Siyasal ve Ekonomik Kökenleri (9. bs.) (çev. Ayşe Buğra). İstanbul: İletişim Yayınları

Senemoğlu, O. (2016), Machiavelli’den Hobbes'a Rönesans Dönemi Siyaset Teorisinde İnsan Doğası ve Toplum Anlayışı, Insan ve İnsan Bilim Kültür Sanat ve Düşünce Dergisi, 3(8), 77-100.

Senemoğlu, O. (2017a), Marx’1 Yeniden Düşünmek: İnsan Doğası, Toplum ve Özgürlük. Ankara: Hece Yayınları.

Senemoğlu, O. (2017b). Tüketim, Tüketim Toplumu ve Tüketim Kültürü: Karşılaştırmalı Bir Analiz, Insan ve Insan Bilim Kültür Sanat ve Düşünce Dergisi, 4(12), 66-88.

Sennett, R. (1997). Yeni Kapitalizm. Defter Dergisi, 64 (2), 31-45.

Sennett, R. (2005). Sayg1: Eşit Olmayan Bir Dünyada (çev. Ümmühan Bardak). İstanbul: Ayrıntı Yayınları

Sennett, R. (2008). Karakter Aşınması: Yeni Kapitalizmde İşin Karakter Üzerindeki Etkisi (3. bs.) (çev. Barış Yıldırım). İstanbul: Ayrıntı Yayınları

Sennett, R. (2011). Yeni Kapitalizmin Kültürü (2. bs.) (çev. Aylin Onacak). İstanbul: Ayrıntı Yayınları

Sennett, R. (2012). Beraber (çev. İkbay Özküralpli). İstanbul: Ayrıntı Yayınları

Sennett, R. (2013). Zanaatkâr (2. bs.) (çev. Melih Pekdemir). İstanbul: Ayrıntı Yayınları

Standing, G. (2017). Prekarya: Yeni Tehlikeli Sınıf (4. bs.) (çev. Ergin Bulut). İstanbul: İletişim Yayınları

Thebaud, A. (2012). Çalışmak Sağlığa Zararlıdır (çev. Ayşe Güren). İstanbul: Ayrıntı Yayınları 
Weeks, K. (2014). Çalıșma Sorunu: Feminizm, Marksizm, Çalıșma Karșıtı Politika ve Çalışma Sonrası Tahayyüller (çev. Tamer Tosun). İstanbul: Ayrıntı Yayınları 